Панкратова О. М., к.е.н., доцент Харківський національний університет імені В. Н. Каразіна Навчально-науковий інститут «Каразінський банківський інститут» м. Харків, Україна DOI: https://doi.org/10.30525/978-9934-26-018-6-2

\title{
ГЛОБАЛІЗАЦІЯ ЯК ОБ'ЄКТИВНИЙ ПРОЦЕС РОЗВИТКУ МІЖНАРОДНОГО БІЗНЕСУ
}

Глобалізація як нове явище в економічному просторі виникло порівняно недавно, в кінці XX століття. Але сьогодні практично всі країни світу залучені в процес глобалізації. На жаль, Україна виступає на сьогоднішній день в ролі тільки приймаючої сторони. Глобальні компанії відкривають свої філії та виробничі 
комплекси в нашій країні, але Україна поки що не здатна освоїти глобальний бізнес.

Доходи західних глобальних компаній дуже високі, вони здатні в даний час витримати конкуренцію і домогтися дійсно високих результатів. Це не означає, однак, що організація діяльності глобальних компаній легша в порівнянні 3 організацією діяльності тих компаній, що оперують тільки на внутрішньому ринку. Існують фактори, які роблять організацію діяльності глобальної компанії більш важкою і комплексної.

Глобальні корпорації розглядають весь світ для своєї діяльності як єдиний ринок. Компанія виробляє і продає товари в різних країнах. При цьому в процесі своєї діяльності на всіх ринках глобальна корпорація використовує однакові товари, єдиний виробничий процес і єдину стратегію. Мати єдину глобальну стратегію для компанії дійсно дуже вигідно. Але розробка такої стратегії досить складний і тривалий процес. Глобальна компанія намагається зробити виробничий процес, продажу та канали розподілу стандартними на всіх ринках, і це іï основна мета. Стандартизація виробництва, як правило, не викликає проблем. Однак, коли компанії ставлять собі завданням стандартизувати продажу і канали розподілу, можуть виникнути певні складнощі.

Ідея глобального маркетингу не є абсолютно новою. Раніше компанії спочатку розробляли продукт для внутрішнього ринку, а потім адаптували його до зарубіжних ринків. В даний час у розвитку глобального маркетингу присутні нові тенденції. Спочатку компанії вивчають та аналізують свої глобальні ринки. Потім для всіх ринків робиться єдиний продукт. Щоб зробити рекламу, компанії шукають глобальні, як би універсальні (загальні) теми. А з урахуванням особливостей (культурних, ментальних, релігійних та інших) конкретних країн реклама потім адаптується до місцевих ринків. Саме від розуміння того, як, де і коли потрібно адаптувати рекламну стратегію або безпосередньо продукт, буде залежати успіх глобального маркетингу. 
Оптимальна модель глобальної торгівлі полягає в стандартизації основних маркетингових складових: product (продукт), price (ціна), place (місце) i promotion (просування товару). Основні переваги стандартизації цієї маркетингової суміші полягають у наступному: по-перше - це зниження витрат; по-друге - суттєво спрощується контроль і координація дій філій з боку головного офісу; по-третє - зменшуються витрати часу на підготовку плану маркетингових заходів.

На швидкість впровадження продукту компанії на зарубіжний ринок впливають особливості зарубіжної країни. Але характеристики самої компанії також впливають на процес впровадження продукції компанії та збільшення обсягів продаж. Компанія, яка бажає вийти на зовнішній ринок, але не має досвіду в міжнародному бізнесі, дуже важко в перший раз представляти свою продукцію тому, що сьогодні на міжнародному ринку діє досить жорстка конкуренція. Для глобальної компанії, що виробляє продукт у різних країнах світу й експортує його в різні країни, не складає великих труднощів завоювати ще один ринок. Адже сутність глобалізації полягає в тому, що компанія використовує єдиний продукт і єдину стратегію на всіх ринках. Тому, використовуючи роками відпрацьовану стратегію, глобальна компанія без особливих додаткових витрат може збільшити обсяги своїх продажів.

Прикладом може служити компанія Coca-Cola. Ця глобальна компанія $\epsilon$ визнаним лідером у виробництві безалкогольних напоїв. Компанія була заснована в 1886 році. Для того, щоб продати свій перший мільярд умовних одиниць продукту, компанії знадобилося двадцять два роки. Зате тепер компанія Coca-Cola найбільш яскраво демонструє те, як процес глобалізації вплинув на збільшення обсягів продажів. Зараз СосаCola продає мільярд умовних одиниць продукту в день, при цьому компанія працює майже в двох сотнях країн.

Збільшення прибутків - це ще одна важлива причина, по якій компанії прагнуть стати глобальними. Збільшення прибутку можливо шляхом збільшення доходів або зменшення витрат. 
Але в умовах глобалізації ситуація часто складається так, що компанії вдається одночасно і збільшити доходи, i знизити витрати.

Одночасного збільшення доходів і обсягів продажів i зниження витрат сприяє уявлення продукту на всіх ринках відразу. Як уже зазначалося, якщо компанія спочатку представляє продукт на внутрішньому ринку або на одному із зарубіжних ринків і, тільки переконавшись, що стратегія була ефективною, виводить продукт на інші ринки, то у конкуруючих компаній буде достатньо часу на освоєння виробництва нового продукту і завоювання ринків.

Багатьом глобальним компаніям вдається збільшити свої прибутки шляхом зниження витрат. Глобальна компанія представляє єдиний стандартний продукт на всіх ринках. Завдяки цьому відпадає необхідність розробляти новий продукт для кожного ринку, що значно знижує витрати компанії на наукові дослідження і розробки. Крім того, якщо компанія присутня на багатьох ринках світу і пропонує стандартний продукт на всіх ринках, то обсяги виробництва цього продукту зростають. Це дозволяє досягти масштабного виробництва і знизити витрати на виробництво одиниці продукції.

Винос глобальними компаніями свого виробництва за кордон також може привести до зниження витрат. Уряди більшості країн не заохочують імпорт, а намагаються залучити інвестиції в країну. Вони намагаються переконати глобальні компанії не експортувати продукт в країну, а виробляти його в самій країні. Такі компанії отримують від держави субсидії на покриття суми відсотків, нарахованої за банківськими кредитами. Крім того, компанії можуть мати низький податок на прибуток. Такі дії уряду країн призводять до зниження витрат на виробництво, однак це не $є$ головною причиною винесення виробництва за кордон. Головною причиною $є$ можливість отримати більший прибуток від виробництва за кордоном.

Не викликає сумніву той факт, що глобалізація дозволяє компаніям стати більшими і багатше. Для того, щоб реально 
оцінити, наскільки великими є на сьогоднішній день глобальні компанії, проводяться кількісні порівняння доходів найбільших глобальних компаній світу. Найбільшою компанією в рейтингу 2018 року зі списку журналу Forbes $є$ китайський комерційний банк ICBC 3 виручкою 165,3 млрд доларів США (18-е місце), чистим прибутком 43,7 млрд доларів США (3-е місце), активами 4210,9 млрд доларів США (1 -е місце) і капіталізацією 311 млрд доларів США (14-е місце) [1]. Ринкова капіталізація 100 провідних корпорацій за рік (з квітня 2018 року по березень 2019 го) склала рекордні \$ 21 трлн. Про це свідчать дані рейтингу Global Top 100 companies, який щорічно складає PricewaterhouseCoopers (PwC) [2].

Проведене порівняння показує, що у компанії немає шансів увійти в число найбільших корпорацій світу без виходу на глобальний ринок. Організацією Об'єднаних Націй підраховано, що 20-25\% сукупного виробництва всіх товарів на світовому ринку забезпечують 600 найбільших глобальних корпорацій.

У наші дні більшість найбільших корпорацій стають глобальними. В даний час жодна глобальна компанія не досягла ідеальної моделі глобалізації (повної стандартизації виробничого процесу, торгівлі та стратегіï). Але процес глобалізації триває, i компанії намагаються якомога ближче підійти до ідеальної моделі. Чим ближче знаходиться компанія до ідеальної моделі, тим більше, сильніше і багатше вона стає. I як наслідок, тим більше вона дає своєї держави, та й іншим країнам, в яких вона працює.

\section{Література:}

1. Forbes Global 2000 - Крупнейшие публичные компании мира. URL: https://www.forbes.com/global2000/list.

2. Глобальный рейтинг 100 крупнейших публичных компаний по рыночной капитализации. URL: https://www.pwc.com/gx/en/services/auditassurance/publications/global-top-100-companies.html\#tab_3-0. 